\title{
The Effects of Cyanate In Vitro on Red Blood Cell Metabolism and Function in Sickle Cell Anemia
}

\author{
Frank G. de Furia, Denis R. Miller, Anthony Cerami, and \\ James M. Manning \\ From the Departments of Pediatrics and Medicine, Cornell University \\ Medical College, New York 10021 and The Rockefeller University, \\ New York 10021
}

\begin{abstract}
A B S T R A C T Cyanate, which is in equilibrium with urea, combines with the $\alpha$-amino group of the aminoterminal valine of hemoglobin in an irreversible, specific carbamylation reaction. Partial carbamylation ( 0.72 residues/hemoglobin tetramer) as determined by cyanate ${ }^{14} \mathrm{C}$ incorporation or hydantoin analysis diminishes the in vitro sickling phenomenon. Since cyanate may react not only with hemoglobin but also with functional groups of other red blood cell proteins, the in vitro effect of cyanate was studied on sickle cells. Cells were incubated with $10 \mathrm{~mm} \mathrm{KCl}$ (control) or $10 \mathrm{~mm} \mathrm{KNCO} \mathrm{(carbamylated)} \mathrm{for} 1 \mathrm{hr}$, washed, and resuspended in autologous plasma. Glycolysis, ATP and 2,3-diphosphoglyceric acid (DPG) stability, autohemolysis, and osmotic fragility were not affected by carbamylation. Potassium loss in carbamylated cells (2.8 $\mathrm{mmol} /$ liter) was less than in control cells (9.0 $\mathrm{mmol} /$ liter $)$. Pyruvate kinase activity of carbamylated cells was decreased $(\sim 25 \%)$ but the activities of other glycolytic enzymes were similar to those of control cells. Oxygen affinity of carbamylated sickle, normal, and DPG-depleted normal cells increased, and was a sensitive index of the degree and duration of reaction with cyanate. The reactivity of carbamylated cells to DPG was similar to control cells. DPG-depleted carbamylated cells regenerated DPG and increased the $P_{50}$ when incubated with pyruvate, inosine, and phosphate. The Bohr effect of normal and of sickle cells was not affected $\left(\Delta \log \mathrm{P}_{50} / \Delta \mathrm{pH}=-0.48\right.$ and -0.53 , respectively) after carbamylation. The reserve buffering capacity of plasma offset the slightly diminished $(\sim 15 \%)$ $\mathrm{CO}_{2}$ capacity of carbamylated cells so that whole blood $\mathrm{CO}_{2}$ capacity, $\mathrm{pH}$, and $\mathrm{P}_{\mathrm{Co}_{2}}$ were normal. These studies provide further support for the potential clinical use of
\end{abstract}

Received for publication 2 September 1971 and in revised form 15 October 1971. cyanate in treating and preventing the anemia and painful crises of sickle cell disease.

\section{INTRODUCTION}

Recent investigations have suggested that intravenous urea in an invert sugar solution may be useful in the treatment and prevention of painful vaso-occlusive crises in patients with sickle cell anemia $(1,2)$. The proposed mechanism of action of this protein denaturant was the disruption of those hydrophobic bonds which may be involved in the polymerization and gelation of the hemoglobin $\mathrm{S}(\mathrm{Hb} \mathrm{S})^{1}$ molecule $(3,4)$. Previous in vitro studies have indicated that concentrations of 1-8 $\mathrm{M}$ are required to unfold a protein (5). Since the maximum concentration of urea achieved in treated patients was approximately $30-50 \mathrm{~mm}$, and since urea is rapidly cleared by the body, an alternative explanation has been presented recently to explain the reported salutary effect of urea-that cyanate, which is in equilibrium with urea (6) (Eq. 1) might be the active agent (7).

$$
\mathrm{H}_{2} \mathrm{~N}-\stackrel{\mathrm{O}}{\mathrm{C}}-\mathrm{NH}_{2} \rightleftharpoons \mathrm{HNCO}+\mathrm{NH}_{3}
$$

\footnotetext{
${ }^{1}$ Abbreviations used in this paper: ACD, acid-citrate-dextrose medium; DHAP, dihydroxyacetone phosphate; DPG, 2,3-diphosphoglyceric acid; FDP, fructose diphosphate; F6P, fructose-6-phosphate; G3P, glyceraldehyde 3-phosphate; G3PD, glyceraldehyde 3-phosphate dehydrogenase; G6P, glucose 6-phosphate; G6PD, glucose 6-phosphate dehydrogenase; GSH-Red, glutathione reductase; GSH-PX, glutathione peroxidase; $\mathrm{Hb}$, hemoglobin; $\mathrm{HK}$, hexokinase; $\mathrm{P}_{50}$, pressure of oxygen in $\mathrm{mm} \mathrm{Hg}$ at which the blood is half saturated; PBS, phosphate-buffered saline; PCA, perchloric acid; PEP, phosphoenolpyruvic acid; PFK, phosphofructokinase; 2PG, 2-phosphoglyceric acid; 3PG, 3 phosphoglyceric acid; PGK, phosphoglycerokinase; PK, pyruvate kinase; RBC, red blood cell; SS, sickle cell disease.
} 
Cerami and Manning (7) studied the effect of cyanate on the sickling phenomenon and found that, in contrast to the high concentration of urea $(1 \mathrm{M})$ required to prevent in vitro sickling, $10-100 \mathrm{~mm}$ potassium cyanate (KNCO) significantly inhibited sickling. They described an irreversible, specific carbamylation reaction in which cyanate reacted with the $\alpha$-amino group of the $\mathrm{NH}_{2}$-terminal valine residue of $\mathrm{Hb} \mathrm{S}$.

$$
\mathrm{HNCO}+\mathrm{RNH}_{2} \Rightarrow \mathrm{RHNCONH}_{2}
$$

Gillette, Manning, and Cerami (8) have shown that the autologous survival of sickle cells treated in vitro with cyanate is prolonged toward the normal range.

These studies $(7,8)$ suggested that cyanate may be efficacious in preventing or treating sickle cell crises. Cyanate is known to react with functional groups of proteins (9-13). Since cyanate may react with other intracellular or membrane enzymes and proteins, we investigated the in vitro effect of cyanate on metabolism and function in the erythrocytes of patients with sickle cell anemia.

\section{METHODS}

Subjects. Blood from patients with electrophoretically proven sickle cell anemia was used for the studies of erythrocyte metabolism and hemoglobin function. The reticulocyte counts ranged between 10 and $20 \%$, and none of the subjects had received a transfusion within 12 months.

Metabolic studies. Venous blood, anticoagulated with heparin was centrifuged at $1200 \mathrm{~g}$ in an International PR6 centrifuge (International Equipment Co., Needham Heights, Mass.) at $4^{\circ} \mathrm{C}$. Plasma was removed, the cells were divided into equal portions, and resuspended in an equal volume of Dulbecco's phosphate-buffered saline (14) $\mathrm{pH} 7.4$ (PBS) containing $10 \mathrm{~mm}$ glucose and either $10 \mathrm{~mm} \mathrm{KCl}$ (control) or $10 \mathrm{~mm}$ KNCO (carbamylated). The cell suspension was incubated for $1 \mathrm{hr}$ at $37^{\circ} \mathrm{C}$ in a shaking metabolic incubator after which the cells were washed twice in PBS and resuspended in leukocyte and platelet-free autologous plasma. Glucose was added to a final concentration of $10 \mathrm{~mm}$ and the suspensions were incubated for $15 \mathrm{~min}$ at $37^{\circ} \mathrm{C}$ and shaken at 90 oscillations per $\mathrm{min}$ in room air. The $15 \mathrm{~min}$ sample (zero time) and 3-hr. samples were deproteinized in $6 \%$ perchloric acid (PCA) and neutralized with $5 \mathrm{M} \mathrm{K}_{2} \mathrm{CO}_{3}$. The $\mathrm{pH}$ remained constant $(\mathrm{pH} 7.4 \pm 0.1)$ throughout the incubation period. Glucose utilization, lactate production, and ATP were measured by previously published methods (15), and 2,3-diphosphoglycerate (DPG) was assayed by the method of Rose and Liebowitz (16). The concentrations of glycolytic intermediates and the adenine nucleotides, AMP and ADP, were determined by the method of Minakami, Suzuki, Saito, and Goshikawa (17). Intracellular sodium and potassium concentrations were measured by flame photometry (18). Glutathione (GSH) and GSH stability of the control and carbamylated cells were determined by the method of Beutler, Duron, and Kelly (19).

A second sample of blood was defibrinated with glass beads and using sterile technique, cells were separated, incubated with either $\mathrm{KCl}$ or $\mathrm{KNCO}$, and washed as described above. Cells were resuspended in the autologous, defibrinated plasma and measurements of osmotic fragility of fresh and incubated cells and of autohemolysis with the addition of saline, glucose, or ATP $(\mathrm{pH} 7.0)$ were performed (20). The activities of the following enzymes in hemolysates of control and carbamylated cells were measured by previously published methods (21): hexokinase $(\mathrm{HK})$, phosphofructokinase (PFK), glyceraldehyde 3phosphate dehydrogenase (G3PD), phosphoglycerokinase (PGK), pyruvate kinase (PK) with $0.4 \mathrm{~mm}$ and $2.0 \mathrm{~mm}$ phosphoenolpyruvate (PEP) and with fructose diphosphate (FDP), glucose 6-phosphate dehydrogenase (G6PD), GSH reductase and GSH peroxidase. A Gilford 2400 automatic recording spectrophotometer (Gilford Instrument Laboratories, Inc., Oberlin, Ohio.) was used for these assays which were performed in duplicate at $37^{\circ} \mathrm{C}$. Methemoglobin was determined by the method of Beutler and Baluda (22) and was less than $1 \%$ in all samples after incubation.

Function studies. Heparinized blood was centrifuged as described above, the plasma set aside, and the cells resuspended in PBS containing the designated concentration of either $\mathrm{KNCO}$ or $\mathrm{KCl}$. Unless otherwise stated the cells were incubated at $37^{\circ} \mathrm{C}$ for $1 \mathrm{hr}$. After the incubation the cells were washed three times with PBS to remove unreacted cyanate. The cells were finally resuspended in autologous plasma or in a $25 \mathrm{~mm} \mathrm{NaHCO}+117 \mathrm{~mm} \mathrm{NaCl}$ solution. The pressure of oxygen in millimeters of $\mathrm{Hg}$ at which the blood was half saturated (the $\mathrm{P}_{50}$ ) was measured by the mixing technique of Edwards and Martin (23). Oxygen saturation was measured in an Instrumentation Laboratory Co-Oximeter (Instrumentation Laboratory Inc., Watertown, Mass.) previously calibrated by the manometric method of van Slyke \& Neill (24). Measurements of $\mathrm{P}_{\mathrm{O}_{2}}, \mathrm{P}_{\mathrm{Co}_{2}}$, and $\mathrm{pH}$ were performed with the Instrumentation Laboratory model 313 Blood Gas Analyzer. For calculation of the $\mathrm{P}_{50}$, the $\mathrm{P}_{\mathrm{O}_{2}}$ values were corrected to $\mathrm{pH} 7.40$ using the Severinghaus nomogram (25).

To evaluate the effect of DPG on the oxygen affinity of carbamylated and control cells, DPG was added to a syringe of whole blood at $50 \%$ oxygen saturation to a final concentration of $1.25 \mathrm{~mm}$. The $\mathrm{P}_{50}$ was determined, the syringe was sealed, and the blood was hemolyzed by freezing and thawing, after which the $P_{50}$ was again determined. The purity of DPG was established by chromatography, electrophoresis, phosphate analysis (26), and enzymatic assay (16). Carbamylated and control cells partially depleted of DPG after storage in ACD (1.1 mM DPG) were suspended in saline containing $10 \mathrm{mEq}$ each of inosine, pyruvate, and phosphate $\left(\mathrm{pH} \mathrm{7.4)}\right.$ and incubated in room air at $37^{\circ} \mathrm{C}$ for $3 \mathrm{hr}$. (27). Portions were analyzed for $\mathrm{P}_{\mathrm{so}}, \mathrm{DPG}$, and ATP at 0 and $3 \mathrm{hr}$.

The Bohr effect of control and carbamylated cells suspended either in $0.015 \mathrm{M}$ Tris in saline $(\mathrm{pH} 7.0,7.4,7.8)$ and tonometered with $\mathrm{CO}_{2}$-free gases, or in saline with bicarbonate $(6.25,25,62.5 \mathrm{mEq})$ and tonometered with gases containing $5.6 \% \quad \mathrm{CO}_{2}$ was calculated after measurement of the $\mathrm{P}_{50}$ by the mixing technique.

$\mathrm{CO}_{2}$ transport at 10,50 , and $90 \%$ oxygen saturations was assessed by comparing the whole blood $\mathrm{CO}_{2}$ and $\mathrm{pH}$, and plasma $\mathrm{CO}_{2}$ of control and carbamylated blood tonometered to either normal or elevated $\mathrm{P}_{\mathrm{CO}_{2}}$ 's. $\mathrm{CO}_{2}$ was determined by a modification of the Natelson microgasometric method (28). Red cell $\Delta \mathrm{pH}$ (plasma $\mathrm{pH}$ - red cell $\mathrm{pH}$ ) was measured at 10,50 , and $90 \%$ saturation $(29,30)$.

Statistical analysis was performed by Student's $t$ test for small samples. 


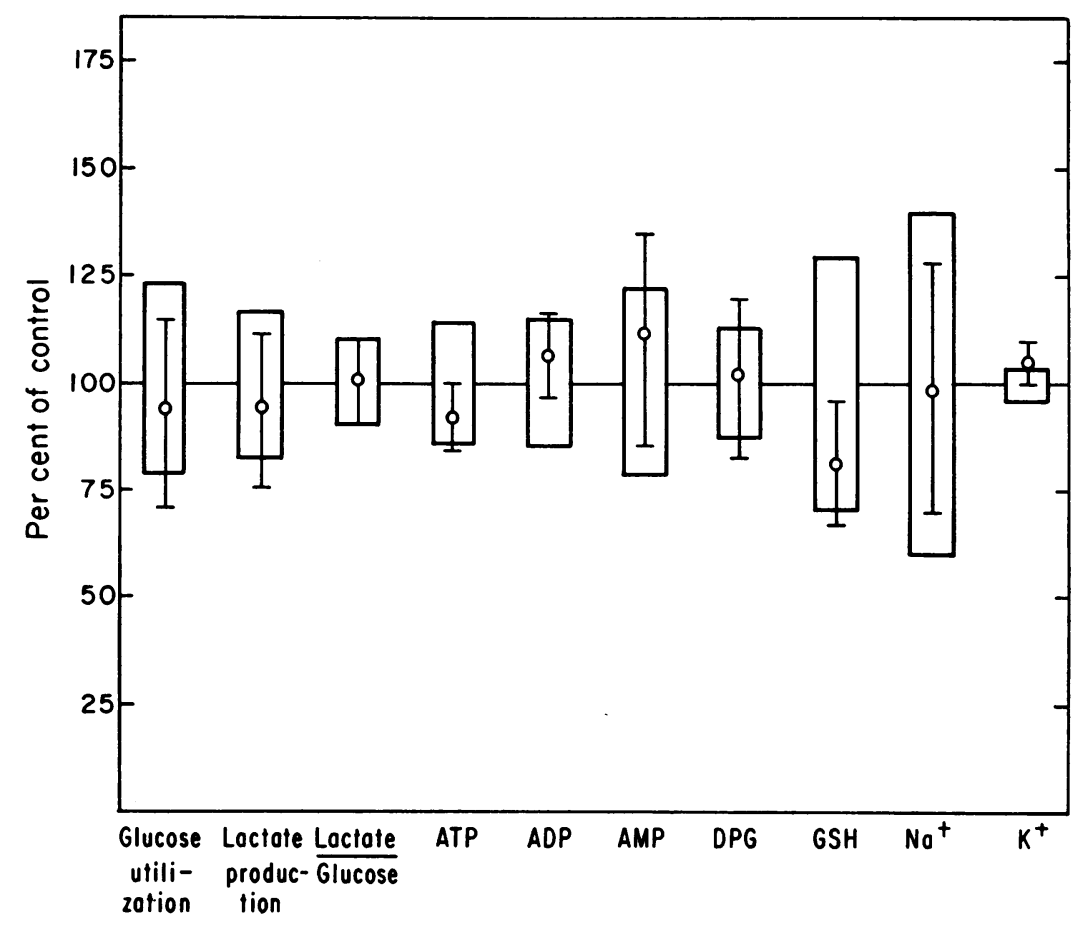

FIGURE 1 The effect of cyanate on glycolysis and intracellular metabolites. Mean (O) and standard deviation (I) of values on sickle cell blood from six patients after incubation with $10 \mathrm{~mm} \mathrm{KNCO}$ for $1 \mathrm{hr}$ at $37^{\circ} \mathrm{C}$ are expressed as per cent of control (treated with $\mathrm{KCl} 10 \mathrm{~mm} \times 1 \mathrm{hr}$ ). Standard deviation of the control value is denoted as the open bar. None of these differences were statistically significant including the decrease in GSH $(0.1$ $>P>0.05$ ).

\section{RESULTS}

Glycolysis and intracellular metabolites. No significant differences were observed in glucose utilization, lactate production, or the concentrations and stability of ATP, ADP, AMP, DPG, and intracellular sodium $\left(\mathrm{Na}^{+}\right)$and potassium $\left(\mathrm{K}^{+}\right)$in control and carbamylated cells (Fig. 1). The lactate: glucose ratios approached the theoretical value of $2: 1$ in both the control and carbamylated samples. During the $3 \mathrm{hr}$ incubation, the mean loss of $\mathrm{K}^{+}$from carbamylated cells was 2.8 mmoles/liter RBC compared to a mean loss of 9.0 mmoles/liter of control cells. Control cells lost 3.0 mmoles of $\mathrm{Na}^{+} /$liter whereas carbamylated cells lost $0.6 \mathrm{mmoles} / \mathrm{liter}$. Autohemolysis and the osmotic fragility of fresh and incubated blood were unaffected by treatment with cyanate.

Glycolytic enzyme activity and glycolytic intermediates. The ratios (carbamylated: control) of activity of the following glycolytic enzymes were slightly altered: G6PD, GSH reductase, GSH peroxidase, HK, PFK, G3PD, and PGK (Fig. 2). Pyruvate kinase was decreased by $21-29 \%$ when assayed at either high or low concentrations of PEP or in the presence of FDP. Although the concentration of GSH in carbamylated cells was lower than that of control cells, the difference was not statistically significant $(0.1>P>0.05)$. After incubation with acetylphenylhydrazine, the GSH content of carbamylated blood rose $29 \%$ whereas a $4 \%$ increase was noted in control cells similarly exposed to acetylphenylhydrazine. The concentrations of glycolytic intermediates in the carbamylated cells were not significantly different from those of control cells except for increased levels of F6P and 2PG and decreased levels of pyruvate (Fig. 3 ).

Oxygen affinity. The oxygen affinity of sickle, normal, and DPG-depleted $(<0.03 \mathrm{~mm})$ cells increased after carbamylation (Fig. 4). The increase in oxygen affinity was irreversible and was not changed by washing the cells free of cyanate after incubation. The decrease in $\mathrm{P}_{80}$ was not due to a loss of DPG or ATP (Fig. 1). The shape and slope of the oxyhemoglobin dissociation curve was not affected by carbamylation.

Oxygen affinity is a sensitive index of the degree of carbamylation (Fig. 5). Incubation of sickle cells with $10 \mathrm{~mm} \mathrm{KNCO}$ for $1 \mathrm{hr}$ resulted in the incorporation of 


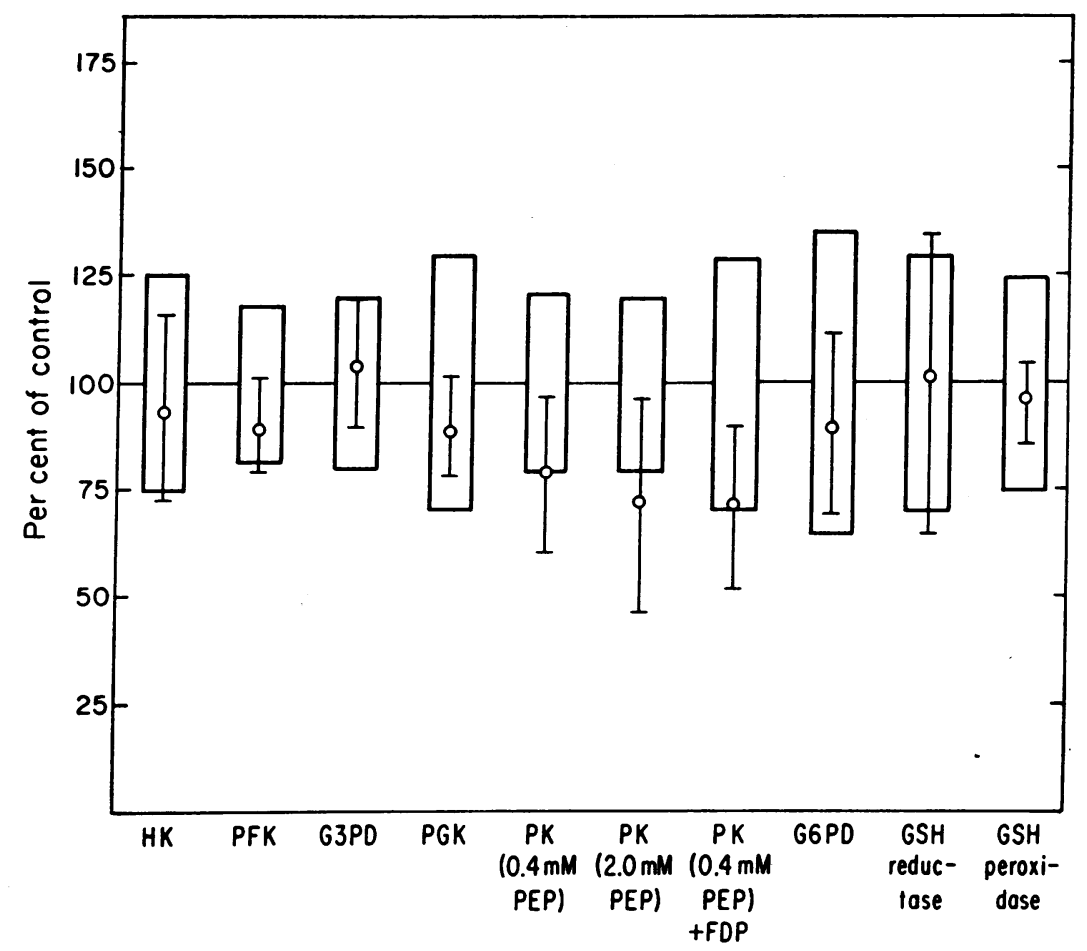

Figure 2 The effect of cyanate on glycolytic enzymes. Mean (O) and standard deviation (I) of enzymatic activity of sickle cell blood from six patients after incubation with $10 \mathrm{~mm} \mathrm{KNCO}$ for $1 \mathrm{hr}$ at $37^{\circ} \mathrm{C}$ expressed as per. cent of control (treated with $\mathrm{KCl} 10 \mathrm{~mm} \times 1 \mathrm{hr}$ ). Standard deviation of the control values are denoted as the open bar. The depression in PK activity was not significant with low substrate concentration $(P=0.10)$ or with low substrate concentration with FDP $(0.10>P>0.05)$ or high substrate $(0.10$ $>P>0.05)$.

0.72 moles of cyanate/mole $\mathrm{Hb}$ tetramer and a decrease of $\mathrm{P}_{\mathrm{s}}$ from 31 to $27 \mathrm{~mm} \mathrm{Hg}$ (Fig. 5). After incubation with $100 \mathrm{mM}$ KNCO the hemoglobin contained 3.9 carbamyl groups per $\mathrm{Hb}$ tetramer and the $\mathrm{P}_{\mathrm{s}}$ had decreased to $19.5 \mathrm{~mm} \mathrm{Hg}$. Similar degrees of carbamylation result after incubation with cyanate in autologous plasma in vitro. Oxygen affinity is also a function of the duration of incubation with $10 \mathrm{mM} \mathrm{KNCO} \mathrm{(Fig.} \mathrm{6).}$

The response of carbamylated cells to DPG was similar to control cells in three experiments (Table I). The $\mathrm{P}_{\mathrm{s}_{0}}$ of $\mathrm{Hb}$ in cells decreases on hemolysis (31-33). The addition of DPG to the hemolysate resulted in an increase in the $P_{50}$. The addition of DPG to the impenetrable whole cells had a negligible effect on the oxygen affinity. The hemolysate of the cell suspension to which DPG had been added did not exhibit a fall in $\mathrm{P}_{\mathrm{so}}$.

The response of DPG-depleted normal cells to incubation with phosphate, inosine, and pyruvate is recorded in Table II. An increase in $P_{s o}$ was noted in DPGdepleted cells after carbamylation and was maintained over a $4 \mathrm{hr}$ period. The $\mathrm{P}_{\mathrm{so}}$ and the concentrations of ATP and DPG were increased similarly in control and carbamylated cells. These results indicate that carbamylated cells are able to synthesize ATP and DPG.

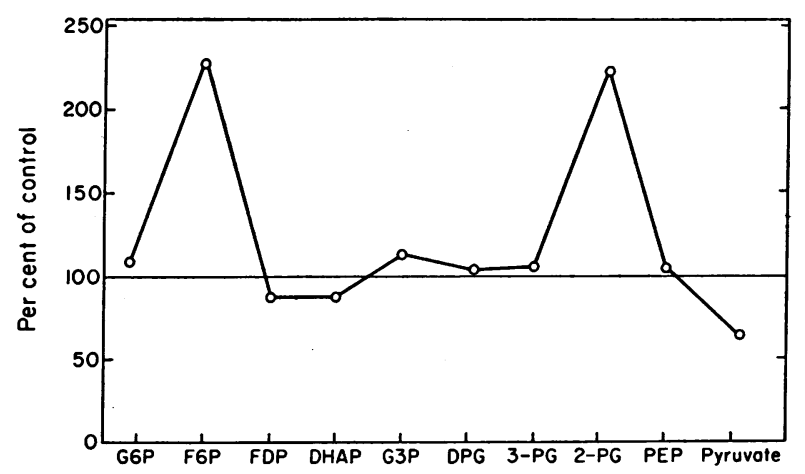

FIGURE 3 The effect of cyanate on glycolytic intermediates. The mean $(O)$ of glycolytic intermediates of sickle cell blood from six patients after carbamylation with $10 \mathrm{mM}$ $\mathrm{KNCO}$ and incubation for $3 \mathrm{hr}$ at $37^{\circ} \mathrm{C}$ is expressed as per cent of control. (The standard deviation of the intermediates expressed as a fraction of the mean are as follows: G6P, \pm 0.36 ; F6P, \pm 1.04 ; FDP, \pm 0.65 ; G3PD, \pm 0.70 ; DHAP, $\pm 0.32 ; 2 \mathrm{PG}, \pm 1.05 ; 3 \mathrm{PG}, \pm 0.70$; PEP, \pm 0.45 ; PYR, \pm 0.21 ). 


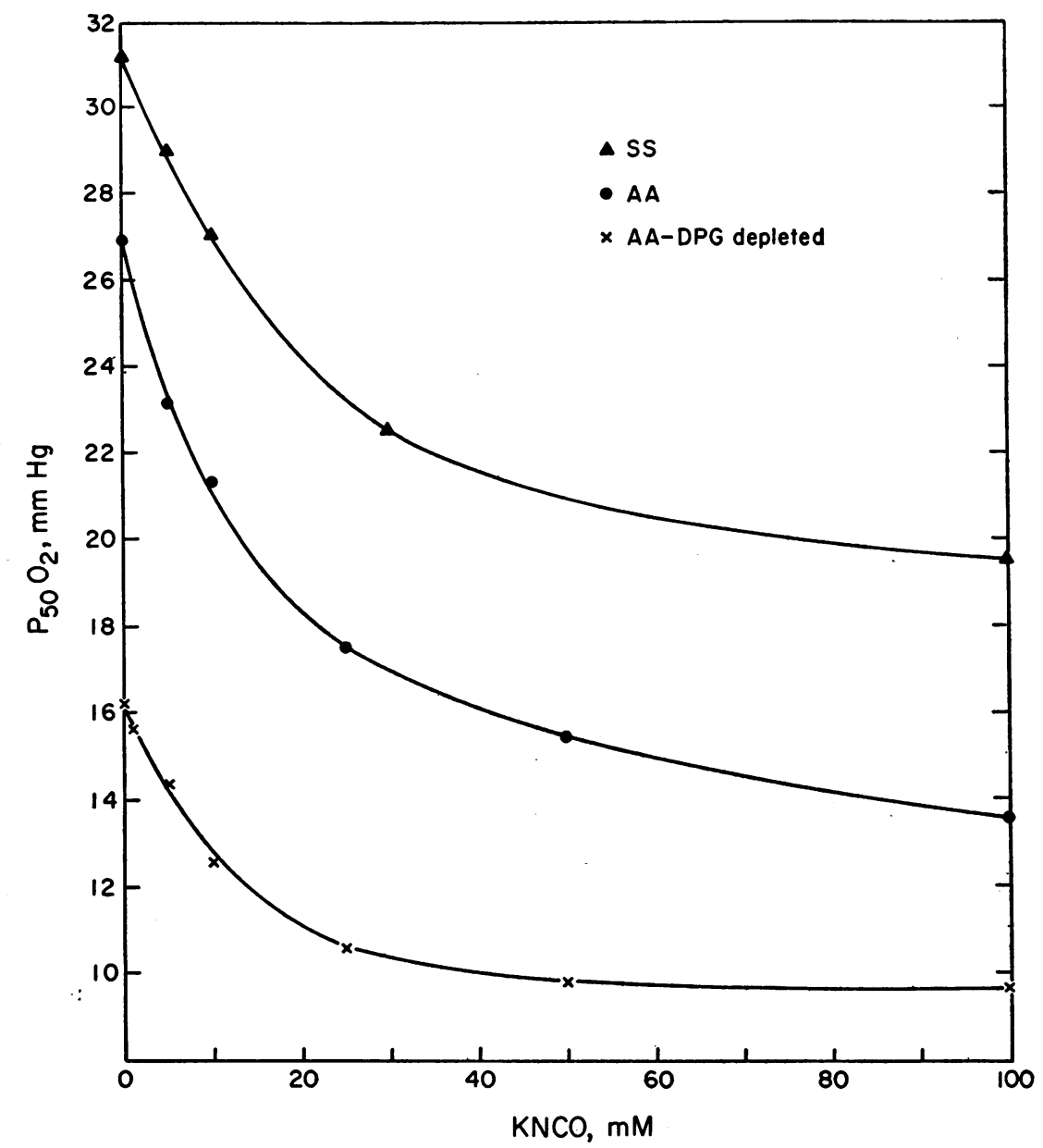

Figure 4 Effect of cyanate on oxygen affinity. Sickle, normal, and normal cells depleted of DPG were incubated for $1 \mathrm{hr}$ at $37^{\circ} \mathrm{C}$ with the indicated concentrations of KNCO. The oxygen affinity, expressed as $P_{50}$, was then determined after the cells were washed and resuspended in autologous plasma. The standard deviation was $0.2 \mathrm{~mm} \mathrm{Hg}$.

The Bohr effect of intact sickle and normal cells suspended in Tris buffer was not altered by carbamylation
(Fig. 7). Similar results were obtained in bicarbonate buffer.

TABLE I

The Effect of DPG on $P_{50}$ *

\begin{tabular}{lccccc}
\hline \multicolumn{1}{c}{ Hb type } & $\begin{array}{c}\text { Carba- } \\
\text { myla- } \\
\text { tion }\end{array}$ & Cells & $\begin{array}{c}\text { Cells } \\
\text { +DPG }\end{array}$ & $\begin{array}{c}\text { Hemoly- } \\
\text { zate }\end{array}$ & $\begin{array}{c}\text { Hemoly- } \\
\text { zate } \\
\text { +DPG }\end{array}$ \\
\hline AA & - & 25.6 & 26.9 & 20.3 & 27.5 \\
AA & + & 21.2 & 21.8 & 20.0 & 25.5 \\
SS & - & 32.7 & 32.8 & 24.4 & 29.8 \\
SS & + & 28.7 & 28.9 & 21.6 & 26.5 \\
DPG-depleted AA & - & 15.9 & 16.2 & 12.3 & 17.1 \\
DPG-depleted AA & + & 12.5 & 12.5 & 8.3 & 12.0 \\
\hline
\end{tabular}

* $\mathrm{P}_{50}$ is the $\mathrm{Po}_{2}$ at $50 \%$ saturation, $\mathrm{pH} 7.4$, and temperature $37^{\circ} \mathrm{C}$. 


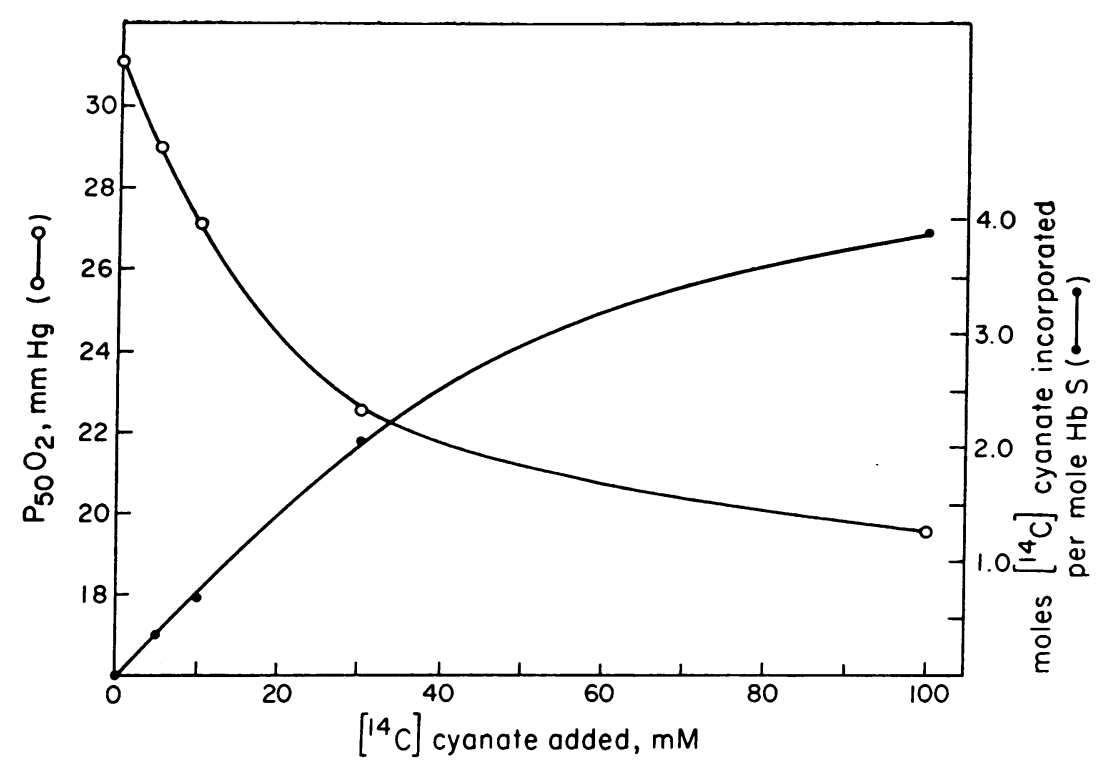

Figure 5 Oxygen affinity as a function of carbamylation. The $\mathrm{P}_{50}$ of the cyanatetreated cells and the amount of $\left[{ }^{14} \mathrm{C}\right]$-cyanate incorporated into acid precipitable protein are plotted as a function of the concentration of cyanate during the 1-hr incubation at $37^{\circ} \mathrm{C}$.

$\mathrm{CO}_{2}$ transport. The whole blood $\mathrm{CO}_{2}$ content and $\mathrm{pH}$ of sickle and normal blood tonometered to the same $\mathrm{PCO}_{2}$ did not change after carbamylation (Table III). A redistribution of $\mathrm{CO}_{2}$ with a $15-20 \%$ decrease in red cell $\mathrm{CO}_{2}$ and compensatory increase in plasma $\mathrm{CO}_{2}$ was regularly noted. The reserve buffer capacity of plasma is sufficient to prevent a difference in blood $\mathrm{pH}$ after carbamylation even after tonometry with elevated $\mathbf{P}_{\mathbf{c o}_{2}}$, e.g., $60 \mathrm{~mm} \mathrm{Hg}$. A slight elevation in whole blood $\mathrm{pH}$ after carbamylation $(0.02 \mathrm{pH} \mathrm{U})$ was noted. The RBC $\Delta \mathrm{pH}$ was not changed significantly after carbamylation (Table III).

\section{DISCUSSION}

The reaction of cyanate with $\mathrm{Hb} \mathrm{S}$ has been shown to inhibit sickling in vitro (7), and to prolong erythrocyte survival in vivo (8). However, similar carbamylation reactions could conceivably occur with other cellular enzymes and proteins, and alter their physiologic function. The results of the metabolic studies indicate that carbamylation causes a slight but insignificant inhibition of overall erythrocyte glycolysis.

Assays of glycolytic enzymes under ideal conditions may not reflect the true status of intracellular glycolysis but our results indicate that there is no significant reduction of the major rate-limiting (34) enzymes of the Embden-Meyerhof pathway. The observations of (a) a slight reduction in the activities of PFK and PK, (b) the elevation of FDP and 2PG and (c) the decrease in pyruvate, suggest altered metabolic activity or so-called "cross-over points" $(35,36)$ at the PFK, enolase, and perhaps the PK steps.

The concentrations of ATP and DPG, which regulate oxygen affinity (32-34) and modulate glycolytic activity $(34,35,37)$ are stable after carbamylation. The normal concentrations of intracellular $\mathrm{Na}^{+}$and $\mathrm{K}^{+}$, the normal osmotic fragility curves, and the normal patterns of autohemolysis suggest that cation-pumping mechanisms are not affected by cyanate and that the integrity of membrane proteins is maintained. In fact, $\mathrm{K}^{+}$loss from carbamylated oxygenated sickle cells was less than that observed in control cells. This is of interest since Tosteson, Carlsen, and Dunham (38), and later Mentzer, August, and Nathan (39) observed an excessive rate of $\mathrm{K}^{+}$loss from deoxygenated sickle cells which the latter investigators correlated with the clinical severity of the disease.

Although the concentration of GSH was lower in carbamylated sickle cells, the activities of GSH per-

TABLE II

Incubation with Inosine, Pyruvate, and Phosphate

\begin{tabular}{lcccccc}
\hline & \multicolumn{2}{c}{ Preincubation } & & \multicolumn{2}{c}{ Postincubation } \\
\cline { 2 - 3 } \cline { 6 - 7 } & $\mathrm{Cl}$ & $\mathrm{NCO}$ & & $\mathrm{Cl}$ & $\mathrm{NCO}$ \\
\hline $\mathrm{P}_{50}$ in $\mathrm{mm} \mathrm{Hg}$ & 18.2 & 14.8 & & 28.8 & 24.7 \\
$\mathrm{DPG}, \mu \mathrm{moles} / \mathrm{ml} \mathrm{RBC}$ & 1.23 & 1.13 & & 3.56 & 3.37 \\
$\mathrm{ATP}, \mu \mathrm{moles} / \mathrm{ml} \mathrm{RBC}$ & 1.37 & 1.40 & & 1.43 & 1.44 \\
\hline
\end{tabular}

Cyanate and Sickle Cell Disease 


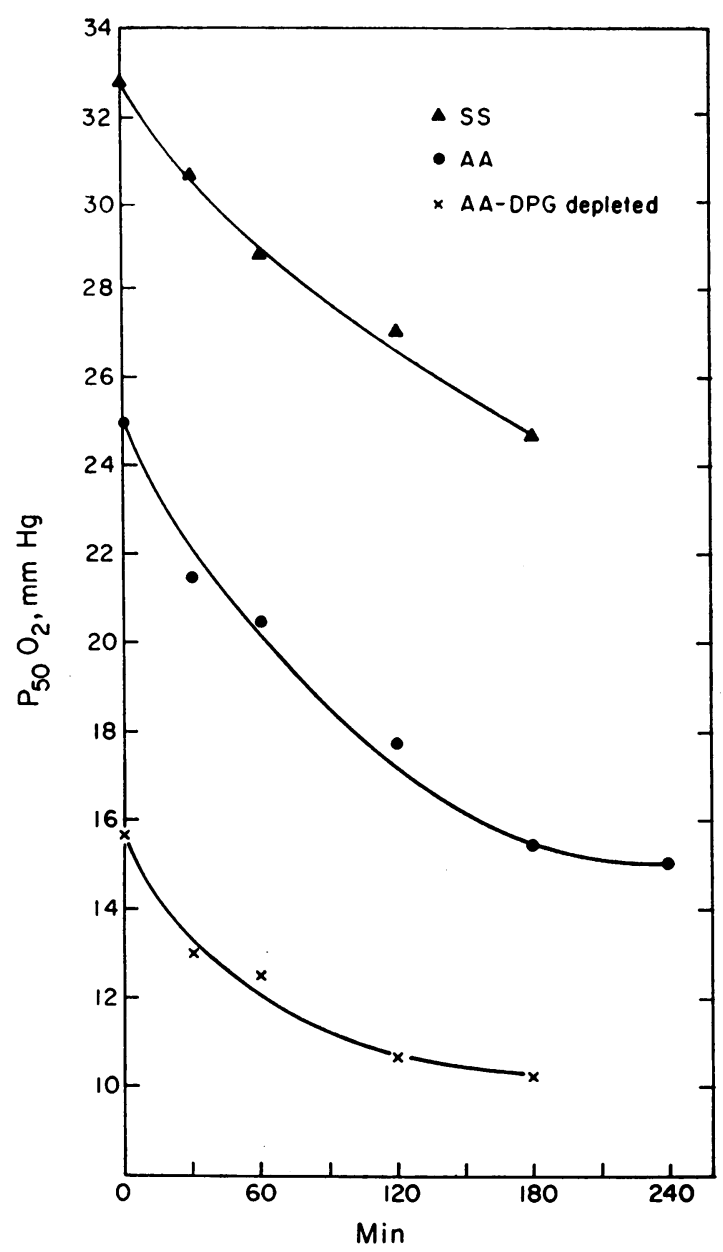

FIGURE 6 Oxygen affinity as a function of duration of incubation with cyanate. Sickle, normal, and DPG-depleted normal cells were incubated at $37^{\circ} \mathrm{C}$ for the indicated time with $10 \mathrm{~mm} \mathrm{KNCO}$. The cells were washed, resuspended in autologous plasma, and $P_{50}$ determined. Cells incubated with $10 \mathrm{mM} \mathrm{KCl}$ decreased their $P_{50}$ less than $1 \mathrm{~mm}$ after a $4 \mathrm{hr}$ incubation.

oxidase and GSH reductase were normal. Furthermore, the elevated levels of GSH occurring in the presence of acetylphenylhydrazine suggest that cyanate does not inhibit the mechanisms available to regenerate GSH.

The irreversible carbamylation of the $\mathrm{NHs}$-terminal valine residues of both $\alpha$ - and $\beta$-chains (unpublished observation) of $\mathrm{Hb}$ might have resulted in an erythrocyte with an altered physiology since these amino groups have been implicated to be directly involved in several important hemoglobin functions. These functions are (a) the binding of $\mathrm{CO}_{2}$ as carbamino groups (40), (b) the Bohr effect $(40,44)$, (c) a binding site for DPG $(41,42)$, and $(d)$ the formation of a salt bridge which stabilizes the deoxy- conformation of hemoglobin (42). In this present communication, we have attempted to assess these functions after carbamylation at levels necessary to inhibit sickling in vitro. $(\sim 1$ mole $\mathrm{NCO}$ incorporated/mole $\mathrm{Hb}$ tetramer.)

It is estimated (43) that $30 \%$ of the expired $\mathrm{CO}_{2}$ is carried as carbamino groups. The carbamylation of all four of the amino-terminal valine residues of horse hemoglobin has been reported by Kilmartin and RossiBernardi (40) to inhibit completely the formation of carbamino compounds with $\mathrm{CO}_{2}$. Under our experimental conditions the carbamylation of one of the four $\mathrm{NH}_{\boldsymbol{2}}$ terminal valine residues of both $\alpha_{-}$and $\beta$-chains of hemoglobin does not lead to a lowered $\mathrm{pH}$ of the blood (Table III). The slight reduction in red cell $\mathrm{CO}_{2}$ levels appears to be compensated for by an increase in the amount of plasma bicarbonate. Approximately 25\% of the Bohr effect of isolated horse hemoglobin has been shown to be due to the protonation of the $\mathrm{NH}_{2-}$ terminal valine residues of the $\alpha$-chain (40). The oxygen affinity of cells which have been carbamylated at one of the four $\mathrm{NH}_{2}$ terminal valines of hemoglobin respond to changes in $\mathrm{pH}$ as do control cells (Fig. 7).

Organic phosphates have been demonstrated to have an effect on the oxygen affinity of isolated hemoglobin and intact erythrocytes. The amino group of the terminal

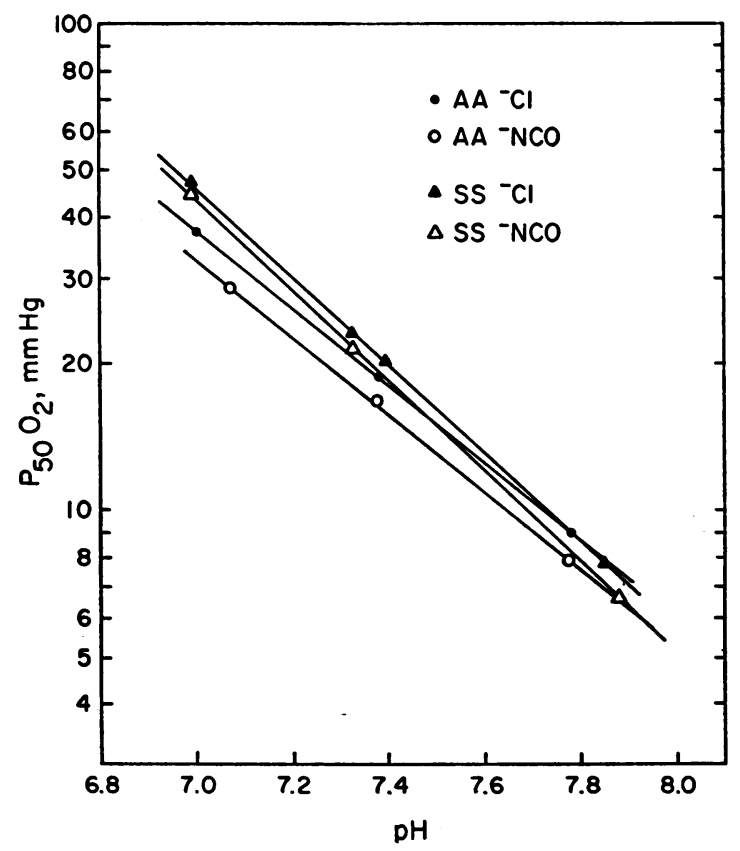

FIgURE 7 The effect of $\mathrm{pH}$ on oxygen affinity after carbamylation. Normal and sickle erythrocytes were incubated with either $10 \mathrm{~mm} \mathrm{KNCO}$ or $10 \mathrm{mM} \mathrm{KCl}$ at $37^{\circ} \mathrm{C}$. After $1 \mathrm{hr}$ the cells were washed and suspended in a solution containing $0.15 \mathrm{M} \mathrm{NaCl}$ and $0.015 \mathrm{M}$ Tris- $\mathrm{HCl}$ buffer. The $\mathrm{P}_{\mathrm{O}_{2}}$ at $50 \%$ saturation and the $\mathrm{pH}$ were measured. The $(\Delta \mathrm{log}$ $\left.\mathrm{P}_{\mathrm{so}}\right) / \Delta \mathrm{pH}$ (Bohr effect) of normal $(-0.48)$ and sickle $(-0.53)$ cells remained in the normal range $(-0.50)$ after carbamylation. 
TABLE III

Blood $^{*} \mathrm{CO}_{2}$ Content after Tonometry

\begin{tabular}{|c|c|c|c|c|c|c|c|c|}
\hline & $\mathrm{Cl}$ & $\mathrm{NCO}$ & $\mathrm{Cl}$ & NCO & $\mathrm{Cl}$ & $\mathrm{NCO}$ & $\mathrm{Cl}$ & $\mathrm{NCO}$ \\
\hline $\mathrm{O}_{2} \%$ saturation & $>90$ & $>90$ & $<10$ & $<10$ & 50 & 50 & 50 & 50 \\
\hline $\mathrm{CO}_{2} \%$ in gas mixture & 5.6 & 5.6 & 6.8 & 6.8 & 6.2 & 6.2 & 8.5 & 8.5 \\
\hline $\mathrm{PCO}_{2} \mathrm{~mm} \mathrm{Hg}$ & 40.1 & 40.2 & 49.0 & 49.0 & 45.4 & 44.8 & 58.5 & 58.6 \\
\hline $\mathrm{pH}$ & 7.26 & 7.28 & 7.26 & 7.27 & 7.23 & 7.26 & 7.20 & 7.21 \\
\hline Total $\mathrm{CO}_{2} \mathrm{mM}$ & 16.79 & 16.94 & 17.69 & 18.09 & 18.18 & 18.23 & 19.19 & 19.11 \\
\hline Plasma $\mathrm{CO}_{2} \mathrm{mM}$ & 18.08 & 19.17 & 17.66 & 20.10 & 17.65 & 19.20 & 18.79 & 19.40 \\
\hline $\mathrm{RBC} \mathrm{CO} 2 \mathrm{~mm} \ddagger$ & 5.94 & 5.44 & 7.09 & 6.03 & 7.59 & 6.70 & 7.92 & 7.47 \\
\hline $\mathrm{RBC} \Delta \mathrm{pH}$ & 0.370 & 0.350 & 0.175 & 0.170 & 0.220 & 0.200 & 0.200 & 0.180 \\
\hline
\end{tabular}

* Hematocrit $=40$

$\ddagger$ Calculated value.

valine residue of the $\beta$-chain has been proposed to be a site of DPG binding on the hemoglobin molecule (41, 42). The oxygen affinities of the hemolysates of carbamylated normal, sickle, and DPG-depleted cells decrease to the same extent as control hemolysates when DPG is added. In addition, the carbamylation of DPG-depleted cells does not interfere with the synthesis of DPG and the concomitant increase in $\mathrm{P}_{s_{0}}$ when the cells are incubated with phosphate, inosine, and pyruvate. Thus, this level of carbamylation does not interfere with the effect of DPG on the oxygen affinity.

The most noteworthy effect of the carbamylation of normal, sickle, and DPG-depleted erythrocytes is the increase in the oxygen affinity of the cells (Fig. 4). Since the levels of DPG and ATP are not affected by carbamylation (Fig. 1), the increased oxygen affinity may be the result of a stabilization of the oxy- conformation of the hemoglobin molecule. Perutz et al. (44) have recently presented evidence from X-ray crystallographic studies that the amino-terminal valine residues form intramolecular salt bridges when hemoglobin is in the deoxy-conformation. The presence of the uncharged carbamyl group on the amino-terminal valine residue may interfere with this salt bridge and stabilize the oxy- conformation.

The stabilization of the oxy- conformation by carbamylation may also explain the antisickling effect of cyanate. Since carbamylated deoxygenated $\mathrm{Hb} \mathrm{S}$ may remain in the oxy- conformation, these molecules may interfere with the aggregation of other noncarbamylated $\mathrm{Hb} \mathrm{S}$ molecules. This hypothesis is consistent with the finding that cells from some patients require as little as 0.1 carbamyl group per hemoglobin tetramer to inhibit sickling (7).

The increased oxygen affinity of carbamylated sickle cells could conceivably lead to decreased oxygen delivery and tissue hypoxia. However, since carbamylation decreases sickling and prolongs the life-span of sickle cells, the red blood cell mass should increase and in- crease oxygen delivery. In addition the cells should be able to increase their DPG concentration and counteract the effects of an increased oxygen affinity. These findings provide further support for the potential clinical use of cyanate in treating and preventing painful vasoocclusive crises of sickle cell anemia.

\section{ACKNOWLEDGMENTS}

These studies would not have been possible without the expert technical assistance of Deanna Ruttenberg, Corinne Barrett, Hortense Craig, Wanda M. Jones, Ann Foster, Steven Hamburger, and James $\mathrm{K}$. Leong.

We are indebted to Dr. Hao-Chia Chen for performing chromatographic analysis of DPG, to $\mathrm{Mr}$. S. Theodore Bella for performing phosphate assays, and to Dr. Peter N. Gillette for providing samples of blood from patients with sickle cell disease.

This work was supported in part by grants from the U. S. Public Health Service (AM 14976, GM 07256, and Contract 21-2371), from the National Science Foundation (GB-20900), and by the Children's Blood Foundation, Inc.

\section{REFERENCES}

1. Barnhart, M. I., J. M. Lusher, R. L. Henry, and R. M. Nalbandian. 1970. Electron microscopic evidence of reversal of sickling in crisis by IV urea in invert sugar. Blood. 36: 837.

2. McCurdy, P. R., and L. Mahmood. 1970. Urea therapy for sickle cell disease. Blood. 36: 841 .

3. Nalbandian, R. M., G. Schultz. J. M. Lusher, J. W. Anderson, and R. L. Henry. 1971. Sickle cell crisis terminated by intravenous urea in sugar solution: a preliminary report Amer. J. Med. Sci. 261: 309.

4. Nalbandian, R. M., editor. 1971. Molecular Aspects of Sickle Cell Hemoglobin. Charles C. Thomas, Publisher, Springfield, Ill.

5. Burk, N. F., and D. M. Greenberg. 1930. The physical chemistry of the proteins in non-aqueous and mixed solvents. I. The state of aggregations of certain proteins in urea-water solutions. J. Biol. Chem. 87: 197.

6. Walker, J., and F. J. Hambly. 1895. Transformation of ammonium cyanate into urea. J. Chem. Soc. (London). $67: 746$.

7. Cerami, A., and J. M. Manning. 1971. Potassium cyanate as an inhibitor of the sickling of red blood cells in vitro. Proc. Nat. Acad. Sci. U. S. A. 68: 1180. 
8. Gillette, P., J. M. Manning, and A. Cerami. 1971. Increased survival of sickle cell erythrocytes after treatment in vitro with sodium cyanate. Proc. Nat. Acad. Sci. U.S. A. 68: 2791

9. Stark, G. R., W. H. Stein, and S. Moore. 1960. Reactions of the cyanate present in aqueous urea with amino acids and proteins. J. Biol. Chem. 235: 3177.

10. Carey, M. J., and P. J. Butterworth. 1969. The action of cyanate on human and pig kidney alkaline phosphatase. Biochem. J. 111: 745.

11. Lindskog, S. 1966. A spectropolarimetric investigation of bovine cobalt carbonic anhydrase. Biochim. Biophys. Acta. $122: 534$.

12. Morris, I., and P. J. Syrett. 1963. Cyanate inhibition of nitrate reductase. Biochim. Biophys. Acta. 77: 649.

13. Bocchini, V., M. R. Alioto, and V. A. Najjar. 1967. The activation of phosphoglucomutase by denaturing agents, urea, guanidine hydrochloride and heat. Biochemistry. $6: 3242$.

14. Dulbecco, R., and M. Vogt. 1954. Plaque formation and isolation of pure lines with poliomyelitis viruses. $J$. Exp. Med. 99: 167.

15. Lichtman, M. A., and D. R. Miller. 1970. Erythrocyte glycolysis, 2,3-diphosphoglycerate and adenosine triphosphate concentration in uremic subjects: relationship to extracellular phosphate concentration. J. Lab. Clin. Med. $76: 267$.

16. Rose, Z. B., and J. Liebowitz. 1970. Direct determination of 2,3-diphosphoglycerate. Anal. Biochem. 35: 177.

17. Minakami, S., C. Suzuki, T. Saito, and H. Goshikawa. 1965. Studies on erythrocyte glycolysis. I. Determination of the glycolytic intermediates in human erythrocytes. J. Biochem. 58: 543.

18. Weed, R. I., and A. J. Bowdler. 1966. Metabolic dependence of the critical hemolytic volume of human erythrocytes: relationship to osmotic fragility and autohemolysis in hereditary spherocytosis and normal red cells. J. Clin. Invest. 45 : 1137.

19. Beutler, E., O. Duron, and B. M. Kelly. 1963. Improved method for the determination of blood glutathione. $J$. Lab. Clin. Med. 61: 882 .

20. Young, L. E., M. J. Izzo, K. I. Altman, and S. N. Swisher. 1956. Studies on spontaneous in vitro autohemolysis in hemolytic disorders. Blood. 11: 977.

21. Paglia, D. E., W. N. Valentine, M. A. Baughan, D. R. Miller, C. L. Reed, and O. R. McIntyre. 1968. An inherited molecular lesion of erythrocyte pyruvate kinase. Identification of a kinetically aberrant isozyme associated with premature hemolysis. J. Clin. Invest. 47: 1929.

22. Beutler, E., and M. S. Baluda. 1963. Methemoglobin reduction. Studies of the interaction between cell populations and of the role of methylene blue. Blood. 22: 323.

23. Edwards, M. J., and R. J. Martin. 1966. Mixing technique for oxygen hemoglobin equilibrium and $\mathrm{Bohr}$ effect. J. Appl. Physiol. $21: 1898$.

24. van Slyke, D. D., and J. M. Neill. 1925. Determinations of gases in blood and other solutions by vacuum extraction and manometric measurement. J. Biol. Chem. $61: 523$.

25. Severinghaus, J. W. 1958. Oxyhemoglobin dissociation curve correction for temperature and $\mathrm{pH}$ variation in human blood. J. Appl. Physiol. 12: 485.
26. Fiske, C. H., and Y. Subbarow. 1925. Colorimetric determination of phosphorus. J. Biol. Chem. 66: 375 .

27. Oski, F. A., S. F. Travis, L. D. Miller, M. DelivoraPapadopoulos, and E. Cannon. 1971. The in vitro restoration of red cell 2,3-diphosphoglycerate levels in banked blood. Blood. $37: 52$.

28. Holaday, D. A., and M. Verosky. 1956. Improved micromanometric methods for the analysis of respiratory gases in plasma and whole blood. J. Lab. Clin. Med. 47: 634 .

29. Battaglia, F. C., R. Behrman, A. E. Hellegers, and J. D. Battaglia. 1965. Intracellular hydrogen ion concentration changes during acute respiratory acidosis and alkalosis. J. Pediat. 66: 737.

30. Hilpert, P., R. G. Fleischmann, D. Kempe, and H. Bartels. 1963. The Bohr effect related to blood and erythrocyte $\mathrm{pH}$. Amer. J. Physiol. 205(2) : 337.

31. Gomez, D. M. 1961. Considerations of oxygen-hemoglobin equilibrium in the physiological states. Amer. J. Physiol. 200: 135.

32. Chanutin, A., and R. R. Curnish. 1967. Effect of organic and inorganic phosphates on the oxygen equilibrium of erythrocytes. Arch. Biochem. Biophys. 121: 96.

33. Benesch, R., R. E. Benesch, and C. I. Yu. 1968. Reciprocal binding of oxygen and diphosphoglycerate by human hemoglobin. Proc. Nat. Acad. Sci. U. S. A. 59: 526.

34. Brewer, G. J., and J. W. Eaton. 1971. Erythrocyte metabolism: interaction with oxygen transport. Science (Washington). 171: 1205.

35. Williamson, J. R. 1970. General Features of Metabolic Control as Applied to the Erythrocyte in Red Cell Metabolism and Function. G. J. Brewer, editor. Plenum Publishing Corporation, New York. 117.

36. Munro, G. F., and D. R. Miller. 1970. Mechanism of fructose diphosphate activation of a mutant pyruvate kinase from human red blood cells. Biochim. Biophys. Acta. $206: 87$.

37. Minakami, S., and H. Yoshikawa. 1966 Studies on erythrocyte glycolysis. II. Free energy changes and rate limiting steps in erythrocyte glycolysis. J. Biochem. (Tokyo). 59: 139 .

38. Tosteson, D. C., E. Carlsen, and E. T. Dunham. 1955. The effects of sickling on ion transport. I. Effects of sickling on potassium transport. J. Gen. Physiol. 39: 31.

39. Mentzer, W. C., C. S. August. and D. G. Nathan. 1969. The effects of androgen administration in sickle cell anemia. Pediat. Res. 3: 378 .

40. Kilmartin, J. V., and L. Rossi-Bernardi. 1969. Inhibition of $\mathrm{CO}_{2}$ combination and reduction of the Bohr effect in haemoglobin chemically modified at its $\alpha$ amino groups. Nature (London). 222: 1243.

41. Bunn, H. F., and R. W. Briehl. 1970. The interaction of 2,3-diphosphoglycerate with various human hemoglobins. J. Clin. Invest. 49 : 1088.

42. Perutz, M. F. 1970. Stereochemistry of cooperative effects in haemoglobin. Nature (London). 228: 726.

43. Rossi-Bernardi, L., and F. J. W. Roughton. 1967. The specific influence of carbon dioxide and carbonate compounds on the buffer power and Bohr effect in human haemoglobin solutions. J. Physiol. 189: 1 .

44. Perutz, M. F., H. Muirhead, L. Mazzarella, R. A. Crowther, J. Greer, and J. V. Kilmartin. 1969. Identification of residues responsible for the alkaline Bohr effect in hemoglobin. Nature (London). 222: 1240. 